\title{
A Study on the Perceptual Differences about Core Competencies between Higher Education and Business Sectors*
}

\author{
Hunseok Oh(吳憲錫)** \\ Yekyung Lee(李禮瓊)***
}

\section{Abstract}

The purpose of this study is to identify differences in the perceptions of core competencies between higher education and the business sector. A total of seven core competencies were identified primarily through literature reviews and focus group interviews by university professors. Based on those 7 competencies, researchers developed a survey focused on asking university professors and business employees to identify the three most important competencies. Surveys mainly including items asking the appropriateness of each competency for college students or corporate workers and items asking the three most important competencies in order, were administered to both groups. A total of 158 university professors and 242 corporate employees participated in the survey. Results demonstrate that university professors valued professional knowledge and creativity, while the business sector valued social skills and values/attitude, competencies usually formed during adolescence. Also, contrary to the belief that the business sector values creativity, corporate employees did not consider it most necessary for executing jobs. Findings of this research suggest that, first, backed by current findings in developmental psychology, professors should reconsider the popular notion that personality development is difficult to achieve after adolescence and incorporate social skills development in their curriculum. Second, universities should self-evaluate their practices and see if they are developing creativity as much as it is emphasized by professors, and third, businesses should eliminate obstacles that block creativity in their culture.

Key words : competency, creativity, social skills, higher education, skilled workers

* This study was conducted by the Korea Human Resource Research Center with the support of the Ministry of Education, Science and Technology.

** Associate Professor, Director of Korea Human Resource Research Center, Seoul National University

*** Correspondence author, Sogang University, Assistant Professor 


\section{I . Introduction}

Current trends of the knowledge-based economy and rising competitiveness among nations call for a highly qualified creative workforce. While the need for highly skilled workers has been increasing, the mismatch between college graduates' competencies and qualifications sought by employers has been of great concern among many nations (Baek, Kim, \& Chun, 2006; European Commission, 2009; Navarro, 2008). Criticism is piling up against universities about their inability to develop individuals into well trained workers with skills necessary for the workplace. Multiple reasons for such criticism exist, such as the lack of practice-based interdisciplinary curriculum (Navarro), the gap between knowledge taught at universities and practical workplace knowledge (Bertsch, 2000), one-size-fits-all elite education (Oh, 2002), and outdated higher education governance systems and excessive government restrictions (Baek et al.). Universities are also blamed for their inaptitude to nurture students into challenging, creative, proactive, and socially refined human beings with integrity (Craft, 2006).

While the expectations for universities from the corporate world are much more complex, the aforementioned criticism represents two types of beliefs about the role of higher education: vocationalism and character development. That is, businesses are demanding that universities teach job skills as well as nurture character, such as creativity and social skills, suitable for the workplace. Vocationalism, the notion that universities should educate students to become highly qualified workers, contradicts traditional beliefs that universities should introduce students into the world of academics and provide structured professional education. The history of higher education demonstrates the emphasis on vocationalism over liberal education by reflecting the practical needs of society and synchronizing colleges and departments to structural changes of the job market (Barnett 2009; Blumenstyk, 2001). This trend is fortified by society's high dependence on intellectual capital in order to succeed in a knowledge-based society (Grubb \& Lazerson, 2005). However, strong influences on higher education by corporations have been constantly criticized for diminishing the role of universities as a place for intellectual inquiry and debate, the fundamental elements sustaining democratic societies (Giroux, 2003; Lustig, 2005).

The second belief is that higher education should be responsible for nurturing competencies other than job specific skills, such as interpersonal or social skills, and overall intellectual competence. This notion shares certain commonalities with liberal education based on the belief that universities should teach knowledge about the broad world along with 
deeper knowledge in specific areas so that students develop social responsibility, interpersonal skills, and intellectual competence (Humphreys, 2006). However, these type of competencies are deeply rooted within the individual and difficult to change compared to job skills (Spencer \& Spencer, 1993). The business world is not only asking universities to teach job skills, but also expecting universities to develop skills that are challenging to nurture.

It is not likely that universities have ignored demands from the business world and society. To various degrees, higher education institutions have embraced vocationalism and social/communication skills development into their curriculum. Universities have demonstrated that they can change with society, and are making efforts to prepare students for their future jobs (Chew \& McInnis-Bowers, 2004). But despite changes in higher education, the business sector is constantly claiming shortage of skilled workers even with college graduates abound in society (Grubb \& Lazerson, 2005). While the results of such studies are capable of pointing out the demands of businesses, they do not yield specific knowledge about what exactly this discrepancy is. It is possible that universities and the business sector value similar competencies but they may not be applicable to the workplace for various reasons such as corporate culture, or that both parties pursue similar competencies that may not easily be developed through college education. That is, the solution to the mismatch might have to be addressed not only by higher education, but the business sector as well. If this is the case, it should be more informative to investigate how core competencies are perceived differently between higher education and the business sector. Various methods such as identifying and comparing core competencies from both parties separately are possible. However, in order to determine what it is that universities are doing that is causing dissatisfaction with the business sector, it would be appropriate to first identify core competencies valued by higher education, and explore how they are perceived at the workplace. By doing this, issues such as whether or not universities are valuing core competencies irrelevant to the workplace, or if the core competencies themselves are essential for the workplace but not encouraged to be used due to factors such as organizational culture, can be clarified.

To summarize, the purpose of this study is to 1) explore the nature of the mismatch between higher education and business needs by investigating how competencies valued at universities are perceived at the actual workplace, 2) explain the roots of these discrepancies, and 3) suggest possible solutions for resolving the discrepancies. The concept of competencies employed in this study will be that of core competencies which are the basic elements necessary for both work and life in general. Researchers of this study considered core 
competencies to be appropriate for this study, as they are the common skills, knowledge, attitudes, and abilities that people need to succeed in any type of job (Kim, Kim, Kim, Lee, \& Jung, 2003; So, 2006). Also, researchers considered it important to identify core competencies valued in universities through the eyes of university professors due to the fact that they are the ones who have direct contact with students and have high influence over how curriculum is actually taught in the classrooms. By identifying the core competencies actually considered important by university professors and seeing how they are perceived at the workplace, researchers expect this study will contribute to developing deeper insights into the problem of the shortage of talented workers in Korea.

\section{П. Literature Review}

\section{Definitions of core competencies}

Since the introduction of the concept of "competence" by psychological studies (McClelland, 1973), multiple disciplines have strived to define its meaning. However, the definition of competence is still under dispute and various definitions exist (le Deist \& Winterton, 2005). A few of the definitions of competence are listed in <Table $1>$. In general, based on existing definitions, competency refers to the skill, knowledge, behavior, or trait of an individual for performing tasks successfully. According to these definitions, competency is defined in reference to successful job performance within task specific contexts rather than independent personal characteristics.

$<$ Table 1> Definitions of competency

Definition

Norton (1997)

Spencer \&

Spencer (1993)

McLagan

(1989)

Rychen \&

Salganik (2003)
The ability, knowledge, skills and attitude to successfully accomplish given tasks; The ability one possesses to execute a given task efficiently.

"an underlying characteristic of an individual that is causally related to criterion-referenced effective and/or superior performance in a job or situation"

"an area of knowledge or skill that is critical for producing key outputs” through the mobilization of psychological prerequisites" 
The concept of individual competency, mostly linked to workplace performance in the beginning, gradually broadened its boundaries to include general life skills for performing tasks. One example is the OECD (2005) definition of competency. The definition proposed by the OECD DeSeCo (Defining and Selecting Key Competencies) project offers an overall view on competencies necessary for the demands of society. According to the DeSeCo definition, competency is "...just more than knowledge and skills. It involves the ability to meet complex demands, by drawing on and mobilizing psychosocial resources (including skills and attitudes) in a particular context" (OECD, 2005: 4). The DeSeCo definition of competency is composed of three categories, the efficient use of tools such as language, information, and technology, the ability to interact in heterogeneous groups through collaboration and conflict resolution, and the ability to act autonomously by planning and conducting one's life independently. It is important to note that the DeSeCo competency model emphasizes autonomous thinking, mature intellect, and a sense of responsibility. Reflection and metacognition on one's thoughts and actions are also important factors considered in the DeSeCo competency model.

In line with the broader definition of competency, the term core competency, or key competency has been discussed in studies to depict the foundational abilities individuals must possess in order to succeed in various life tasks (Kim et al., 2003; Lim, Choi, \& Park, 2008). Core competencies are relevant to job specific competencies in the sense that job specific competencies share common elements that are not only applicable to job related tasks, but also to the individual's personal and social life (Lim et al.). In other words, a person with high levels of core competencies will thrive in both his/her personal life and career. Core competencies not only include context specific skills, but also social and behavioral elements such as attitude, value, and motivation, which are necessary for individuals to perform tasks in various contexts (So, 2006).

The concept of core competencies can also be found in the research about "life competency" conducted by the Korean Educational Development Institute (Kim et al., 2003). According to this study, life competency implies abilities required for living a successful life, and includes basic literacy, key skills, citizenship, and job specific skills. Among these four elements of life competency, key skills can be construed as core competencies. Key skills are defined as the most basic skills necessary for personal and social life as well as successful performance in 
one's career. The more complex and developed society becomes, the level of key skills required for individuals also increases (Kim et al.). Elements of key skills that should be developed at all levels of education according to this study are communication skills, problem solving skills, self-directed learning skills, and leadership. Professional knowledge is discussed as an important competency that should be developed in higher education.

To summarize, competency can be defined as skills, knowledge, attitudes, and abilities for successful task performance. Originally competency was defined in reference to workplace skills, but its meaning evolved into one that encompasses various life skills. The broader concept of competency is in line with the KEDI study on core competencies (Kim et al., 2003) which are the fundamental abilities required regardless of the type of jobs and also necessary for success in various life tasks.

\section{Core competencies for universities and businesses}

Competencies pursued in universities and the business sector are not substantially different from the core competencies previously explained. The competencies universities value differ depending on the goals of the institution, departmental characteristics, and strength of partnership with corporations. Diverse perspectives on core competencies run the spectrum of vocationalism to liberal education. From a perspective focused on liberal education, literature on the roles of higher education suggest that universities should promote liberal education rather than job specific skills so as to produce intellectuals capable of creating knowledge. According to Hutchins (1968), the role of universities is to nurture students into intelligent humans capable of creating knowledge, rather than merely have them gain knowledge or train them into skilled workers. Universities focusing their efforts on cultivating students' intelligence emphasize liberal education rather than pragmatic training. From a political view, liberal education is a central source for the democratic and civic life of a nation. That is, universities should maintain its role as a place for dialogue based on critical thinking and ethical reflections to take place, and strengthen democracy rather than submit themselves to the demands of corporations. However, more and more universities are giving up to the demands of the marketplace in exchange for funds, and are pursuing vocationalism in the curriculum so that their students' values in the marketplace will increase (Giroux, 2003). The specific curriculum of liberal education consists of traditional disciplines 
such as metaphysics, social science, and natural sciences. Advocates of liberal education believe that higher order knowledge taught in these subjects can foster students' critical thinking about nature and society, and make them capable of thinking beyond the present situation into the future (Wheelahan, 2007).

Current trends emphasizing education that promotes creativity, critical thinking, and communication skills can be considered to overlap with vocationalism and liberal education. Increased attention towards national economic competitiveness has raised the need for talented workers who can critically analyze issues from various perspectives and produce creative solutions while collaborating with people from different backgrounds (Beechler \& Woodward, 2009). This trend implies that universities are geared toward fostering the growth of intelligence usable in the long term, rather than job specific skills. This perspective requires higher education to align their goals with expectations of society, but also accentuates the values and benefits of liberal education which is challenging students intellectually and broadening their views of the world surrounding them (Jones, 2005).

Literature on the perspectives of businesses show, in general, that soft skills such as social skills, communication, and leadership are important requirements for employment and success in work as well as job specific skills. The value of soft skills accumulated through experiences in work and study rather than 'degree-specific knowledge' is demonstrated through a number of studies (Hodges \& Burchell, 2003; Park \& Song, 2008; Raybould \& Sheedy, 2005; Yang, Kim, \& Joo, 2006; Yoo, Kim, Park, et al., 2008). A study (Park \& Song) on the perceptual differences of college graduates' competencies between large scale company HR managers and college students reveal that HR managers emphasize ethics, etiquette, and attitude, but do not consider professional and global competence as important as college students. According to this study, businesses consider on-site training more effective than professional education in college, and emphasize basic competency required for performing various tasks rather than professional knowledge. Research on CEOs' and HR managers' perceptions and needs regarding higher education (Yang et al.), suggests that although there may be differences depending on the company's situation, local companies tend to stress the importance of personality (e.g., ethics, diligence, responsibility), and international companies mostly regard job related competence, such as learning ability, foreign language skills, and professional knowledge, more important than personality factors. An analysis of 211 out of the top 300 Korean companies' perceptions of highly sought out workers reveal that 
creativity, professionalism, openness towards challenge, and global competence were considered most important (Yoo et al.). Co-operation, customer oriented attitude, proclivity towards innovation and change, and responsibility were also deemed important by this study.

The emphasis put on soft skills by the business world leads to the need for education nurturing skills useful for various tasks and jobs in the long term, rather than education narrowly focused on specific knowledge domains. For instance, research (Astin, 2001) indicates that majoring in a specific domain of knowledge, such as engineering or business, is negatively associated with crucial skills for work, such as writing ability, openness towards other cultures and people, and foreign language skills. Reports from businesses also support the need for general education, explaining the necessity of liberal education to develop those skills. Former chief executive officer of General Motors, Roger Smith (1987) asserts that to develop the ability to "tolerate ambiguity" and "bring order out of apparent confusion", liberal arts are the most relevant learning model.

The Federation of Korean Industries' 2006 survey demonstrates the fact that $51.8 \%$ of the employers who responded to this survey were not satisfied with college graduates' competencies, and the lack of skilled workers was a serious problem in the area of science and technology. This survey suggests that universities should develop curriculum reflecting the needs of society, and make an effort to develop skills needed for jobs such as foreign language skills, business etiquette, creativity, communication skills, and cooperation (Baek et al. 2006).

Overall, research in competencies pursued in higher education and the business sector suggest that although specific job related skills are necessary for completing tasks successfully at the workplace, it is important for individuals to possess competencies such as creativity, critical thinking, and communications skills that are useful for solving various problems in a world full of complexity. This is in line with the aforementioned concept of core competencies. Both higher education and the business sector are aware that core competencies rather than specific job skills are essential for meeting the complex demands of society. Core competencies identified in the literature can be summarized into communication skills (Baek et al., 2006; Kim et al., 2003; OECD, 2005), autonomy or self-directed learning (Kim et al.; OECD), problem solving skills (Kim et al. Smith, 1987), leadership (Kim et al.), attitude (Park \& Song, 2008; So, 2006; Yang et al., 2006), creativity (Baek et al.; Yoo et al., 2008), critical thinking (Giroux, 2003; Wheelahan, 2007), and professional knowledge (Kim et al.; Yang et 
al.). Previous studies on competency models representing necessary skills for the Korean workforce (Na, Jang, Seo, et al., 2003; Jin, Lee, and Song, 2007; Jung, 1998; Lim et al., 2008) support this list of core competencies identified from the literature review. For instance, communication skills, leadership, problem solving skills, autonomy or self-directed learning, and critical thinking are simultaneously identified in competency models of the Korean workforce. Based on this observation, this study examined how these core competencies were valued in higher education and the business sector.

\section{Methods}

In order to examine perceptual differences of core competencies between universities and the business sector, seven competencies were first selected based on literature reviews on competency and business needs, and interviews with professors. A survey asking perceptions of the 7 competencies followed. Specific data collection and analysis methods are described in this section.

\section{Data collection}

In order to identify which competencies are perceived to be of highest importance, researchers of this study first identified a list of core competencies from existing literature, and then revised this list based on the results of focus group interviews with professors from a large scale university. Once the list was finalized, a survey asking the importance of these competencies within the higher education sector was administered to professors at the same university.

Specifically, core competencies identified from the literature were communication skills, autonomy or self-directed learning, problem solving skills, leadership, attitude, creativity, critical thinking, and professional knowledge. These core competencies formed the basic framework for the focus group interview protocol. Researchers arranged three separate focus groups each composed of 4-5 university professors, and asked about the importance and meaning of these competencies in college education. The three focus groups consisted of professors from various colleges within the university. The contents of the focus group 
interviews were then analyzed in order to revise the preliminary list of core competencies. A content analysis of the interview transcript was conducted based on the research goals and interview protocol. The categorization system developed for the transcripts included items such as 'competencies developed well in college', 'competencies not developed well in college', and 'competencies that should be developed in college'.

The initial analysis of the transcripts and existing literature produced a list of core competencies consisting of intellectual ability, basic academic ability, foreign language skills, communication skills, creativity, leadership, interpersonal skills, and personality. However, the researchers agreed that the boundaries for certain competencies were vague, and decided to revise the categorization of the initial analysis. As a result, intellectual ability, basic academic ability, foreign language skills, and personality were renamed as 'logical thinking', 'professional knowledge', 'learning ability', and 'values and attitude' respectively. Researchers also decided to include communication skills under interpersonal skills.

To summarize, based on literature reviews and content analysis of focus group interviews, seven core competencies and their components that are most important for college students were identified. The 7 competencies and their components (in parentheses) are; professional knowledge (basic theory and practical knowledge), learning ability (self-directed learning, informational technology implementation skills, foreign language abilities), creativity (novelty, adaptability), critical thinking (higher order thinking, analytical and logical thinking), social skills (communication, collaborative work skills, openness), leadership (decision making, broad perspective, challenging attitude), and values and attitude (respect for community, ethics, consideration of others).

An online survey was created based on those seven competencies and administered to university professors of a large scale university located at a metropolitan area. The online survey asked the appropriateness of each competency for being elected as core competencies to be developed in higher education. Respondents were also asked to rate the three most important competencies. Items asking the sex, age, teaching experience, and college of the respondent were also included. A scale of 1 (not appropriate at all) to 4 (very appropriate) was used to rate the appropriateness of each competency.

The survey created for the business sector used the same items as those provided to the professors, except for partial adaptations made for the business sector. Items asking the necessity of each competency for carrying out tasks, items asking to rate the three most 
important competencies in the business world, and questions on the sex, age, position, years of experience, and education were included in the survey.

Rank order scale was the preferred method, since the main purpose of this study was to identify the priority placed on a competency in comparison to others. If a likert scale were to be used, comparison among the competencies would have reflected the individual value put on each of the competencies, rather than display relative importance put on each competency. In this study, as the 7 competencies are those considered to be of high importance in education and society in general, it is possible that the scores for each of the competencies might hardly have shown any variation among themselves. If scores for the competencies show minimal differences, for instance, .1 or .2, while others are around 1.0, considering the competency with such a minor difference as the competency of higher priority would have been problematic. Considering the issues of implementing a likert scale, researchers of this study determined to use rank order scale instead. It was expected that if participants are forced to rank the top three competencies, the amount of priority would be manifested more clearly compared to data produced by likert scales.

\section{Participants and Sampling Method}

The online survey for university professors was provided to members of a large scale national university in Korea. Among the 1555 members of this university, 158 (10.16\%) responded to the online survey. Respondents included professors from various fields including science and technology (30.4\%), liberal arts $(28.5 \%)$, medical and pharmaceutical science $(20.4 \%)$, education $(12.7 \%)$, and the performing arts $(3.2 \%)$. The majority were males $(85 \%)$, and the age of $68 \%$ of the professors were 45 or over. The percentage of those whose years of experience as a professor were under 5 years and 5-10 years were similar (22\%), while that of those whose experience exceeded 25 years was considerably lower (12\%).

A total of 256 participants from 6 companies participated in the survey for the business sector. These companies have been recently acknowledged for their creative ideas and products. Four were large scale, and the other two were mid scale companies. The four large scale companies were in the field of automobile services, manufacturing and sales, automobile manufacturing and sales, and informational technology and networking. The two mid scale companies were in the field of online content development and networking services. 178 from 
the large scale companies, and 64 participants from the mid scale companies answered the surveys.

Among the business sector participants $57.4 \%$ were males, and the majority (65.3\%) was in their 30's. Among the participants, 64\% had work experiences for 5 years or below, while $27 \%$ had 5 to 10 years of experience. That is, a majority of the business sector participants had been working for 10 years or less. Positions of the business sector participants consisted of associates (37.2\%), entry level employees (28.9\%), and managers (27.7\%). Over half of the participants $(69.3 \%)$ had either a bachelor's or master's degree, while $24.1 \%$ had high school degrees only. Participants' jobs included sales and services (42.3\%), R\&D (23.1\%), and training $(17.1 \%)$.

\section{Data analysis}

In order to analyze the survey responses to identify the most important core competencies recognized by both participant groups, participants rated the appropriateness for each of the seven competencies and also ranked the three most important ones. Further analysis was conducted only for the first two highly rated competencies. Researchers considered that participants' judgment could have been less articulate when it comes to rating the third most important competency compared to the first two.

Chi-square analysis for identifying differences between groups in terms of ratings, and logistic regression analysis for identifying any differences in terms of the combination of the first and second rated competencies were conducted along with basic descriptive statistics of the survey responses.

\section{Results}

\section{The two most highly rated core competencies}

Survey results demonstrate that professors considered all seven competencies worth nurturing in college students (Table 2). Survey results from the business sector also indicate that all of the competencies were considered appropriate and necessary for carrying out tasks at the workplace (Table 3). 
$<$ Table 2> Appropriateness of competencies for college students (University)

\begin{tabular}{ccccc}
\hline \multirow{2}{*}{ Core Competencies } & \multicolumn{4}{c}{ Participants (\%) } \\
\cline { 2 - 5 } & $\begin{array}{c}\text { Not appropriate } \\
\text { at all }\end{array}$ & $\begin{array}{c}\text { Somewhat not } \\
\text { appropriate }\end{array}$ & $\begin{array}{c}\text { Somewhat } \\
\text { appropriate }\end{array}$ & $\begin{array}{c}\text { Very } \\
\text { appropriate }\end{array}$ \\
\hline Professional knowledge & $3(2)$ & $11(7)$ & $67(42)$ & $77(49)$ \\
Logical thinking & $0(0)$ & $17(11)$ & $52(33)$ & $89(56)$ \\
Learning ability & $3(2)$ & $6(4)$ & $78(49)$ & $71(45)$ \\
Creativity & $3(2)$ & $19(12)$ & $55(35)$ & $81(51)$ \\
Leadership & $6(4)$ & $27(17)$ & $52(33)$ & $73(46)$ \\
Social skills & $2(1)$ & $33(21)$ & $62(39)$ & $61(39)$ \\
Values and attitude & $6(4)$ & $22(14)$ & $55(35)$ & $75(47)$ \\
\hline
\end{tabular}

$<$ Table 3> Appropriateness for employees (Business)

\begin{tabular}{ccccc}
\hline \multirow{2}{*}{ Core Competencies } & \multicolumn{4}{c}{ Participants $(\%)$} \\
\cline { 2 - 5 } & $\begin{array}{c}\text { Not appropriate } \\
\text { at all }\end{array}$ & $\begin{array}{c}\text { Somewhat not } \\
\text { appropriate }\end{array}$ & $\begin{array}{c}\text { Somewhat } \\
\text { appropriate }\end{array}$ & $\begin{array}{c}\text { Very } \\
\text { appropriate }\end{array}$ \\
\hline Professional knowledge & $8(3)$ & $20(8)$ & $131(54)$ & $82(34)$ \\
Logical thinking & $0(0)$ & $7(3)$ & $123(50)$ & $110(46)$ \\
Learning ability & $1(.4)$ & $21(9)$ & $148(61)$ & $71(29)$ \\
Creativity & $3(1)$ & $16(7)$ & $137(58)$ & $82(34)$ \\
Leadership & $1(.4)$ & $13(5)$ & $123(51)$ & $103(43)$ \\
Social skills & $0(0)$ & $3(1)$ & $93(38)$ & $144(60)$ \\
Values and attitude & $0(0)$ & $5(2)$ & $134(55)$ & $102(42)$ \\
\hline
\end{tabular}

The two most highly rated competencies are shown in <Table $4>$ and $<$ Table $5>$.

$<$ Table 4> 1st and 2nd ranked competencies (University)

\begin{tabular}{crr}
\hline & \multicolumn{2}{c}{ Participants $(\%)$} \\
\hline Core Competencies & \multicolumn{1}{c}{1 st } & \multicolumn{1}{c}{ 2nd } \\
\hline Professional knowledge & $42(26.6 \%)$ & $12(7 \%)$ \\
Logical thinking & $20(12.7 \%)$ & $33(20.9 \%)$ \\
Learning ability & $5(3.2 \%)$ & $7(4.4 \%)$ \\
Creativity & $42(26.6 \%)$ & $37(23.4 \%)$ \\
Leadership & $15(9.5 \%)$ & $26(16.5 \%)$ \\
Social skills & $4(2.5 \%)$ & $15(9.5 \%)$ \\
Values and attitude & $30(19.0 \%)$ & $28(17.7 \%)$ \\
\hline Valid & $158(100 \%)$ & $158(100 \%)$ \\
No answer & 0 & 0 \\
\hline Total & 158 & 158 \\
\hline
\end{tabular}




\begin{tabular}{crr}
\hline Table 5> 1st and 2nd ranked competencies (Business) \\
\hline & \multicolumn{2}{c}{ Participants $(\%)$} \\
\hline Core Competencies & 1 st & \multicolumn{1}{c}{ 2nd } \\
\hline Professional knowledge & $26(10.7 \%)$ & $31(12.8 \%)$ \\
Logical thinking & $35(14.5 \%)$ & $47(19.4 \%)$ \\
Learning ability & $29(12.0 \%)$ & $24(9.9 \%)$ \\
Creativity & $26(10.7 \%)$ & $20(8.3 \%)$ \\
Leadership & $33(13.6 \%)$ & $25(10.3 \%)$ \\
Social skills & $45(18.6 \%)$ & $66(27.3 \%)$ \\
Values and attitude & $41(16.9 \%)$ & $23(9.5 \%)$ \\
\hline Valid & $235(97.1 \%)$ & $236(97.5 \%)$ \\
No answer & $7(2.9 \%)$ & $6(2.5 \%)$ \\
\hline Total & $242(100 \%)$ & $242(100 \%)$ \\
\hline
\end{tabular}

Survey results of the professors for the three most valued competencies, indicate that for the first choice, knowledge and creativity were equally chosen. Following these two, was creativity. Business employees most frequently chose social skills for both first and second place. The competency most frequently chosen for first place other than social skills was values and attitude.

Contrary to responses from the professors, the frequency of first choice for professional knowledge and creativity by the business sector was lowest (each 11\%). Also, regarding the competency most frequently chosen as first choice by the business sector, social skills, only $2.5 \%$ of university professors ranked it as first choice. The second most frequently ranked competency for first choice by the business sector, values and attitude (17\%), was considered similarly by professors (19\%). With the exception of values and attitude, the competencies one group ranked highly was considered the opposite to the other group.

The proportions of competencies chosen as first choice for both groups indicate that over half of the professors ranked creativity and professional knowledge as the most important competency. When logical thinking and values and attitude are considered together, over $90 \%$ of the professors chose these four competencies as most important. The business sector responses did not show heavy concentration on any of the competencies. 


\section{Statistical analysis on differences between groups}

A chi-square analysis was conducted to identify any differences between the two groups in terms of first and second choice competencies. Analysis was carried out separately for each first choice, and statistically meaningful differences were found for both $(a=.05$; 1st choice, $\mathrm{X}^{2}=54.48, \mathrm{p}<.05 ;$ 2nd choice $\left.\mathrm{X}^{2}=44.15, \mathrm{p}<.05\right)$.

Statistical analysis was also carried out to see if there were any differences in combinations of 1st and 2nd choice for each group. Frequencies of all combinations for 1st and 2nd choices show that 45 types of combinations exist. However, as there were no substantially dominant combinations, and even the combinations with the highest frequencies only made up a small proportion of the total, further statistical analysis for comparing groups could not be carried out. That is, a dominant combination for each group enough to carry out statistical analysis could not be identified. The top five combinations with the highest frequencies are listed in $<$ Table $6>$ and $<$ Table $7>$. Both tables indicate that there are no prominent combinations of 1st and 2nd choice of the most important competencies for both groups. The combination of most important competencies chosen by professors take up only a small proportion within the total combinations of the business sector group, and vice versa.

$<$ Table 6> Top 5 combinations of 1st and 2nd choice for most important competencies: University

\begin{tabular}{ccc}
\hline Top 5 combinations chosen by professors & $\begin{array}{c}\text { Professors } \\
(\mathrm{n}=158)\end{array}$ & $\begin{array}{c}\text { Business } \\
\text { employees }(\mathrm{n}=237)\end{array}$ \\
\hline Creativity - Logical thinking & $13(8.2 \%)$ & $3(1.3 \%)$ \\
Creativity - Leadership & $13(8.2 \%)$ & $1(.42 \%)$ \\
Professional knowledge - Logical thinking & $12(7.6 \%)$ & $8(3.4 \%)$ \\
Professional knowledge - Values and attitude & $11(7 \%)$ & $4(1.7 \%)$ \\
Logical thinking - Creativity & $11(7 \%)$ & $2(.8 \%)$ \\
\hline
\end{tabular}

$<$ Table 7> Top 5 combinations of 1 st and 2nd choice for most important competencies: Businesses

\begin{tabular}{ccc}
\hline Top 5 combinations chosen by business employees & $\begin{array}{c}\text { Business } \\
\text { employees }(\mathrm{n}=237)\end{array}$ & $\begin{array}{c}\text { Professors } \\
(\mathrm{n}=158)\end{array}$ \\
\hline Values and attitude - Social skills & $20(8.4)$ & $6(3.8 \%)$ \\
Creativity - Social skills & $14(5.9)$ & $2(1.3 \%)$ \\
Leadership - Logical thinking & $12(5)$ & $0(0 \%)$ \\
Logical thinking - Social skills & $11(4.6)$ & $0(0 \%)$ \\
Social skills - Leadership & $11(4.6)$ & $1(.6 \%)$ \\
\hline
\end{tabular}


Based on these results showing low frequencies for all combinations, logistic regression analysis could not be implemented to identify any statistical differences between groups. For instance, even if a logistic regression analysis were carried out with the result of a statistical meaningful difference between groups, as the combination with the highest frequency 'values and attitude - social skills' takes up only $8.4 \%$ of the total number of combinations, the results would not carry much meaning.

\section{Discussion and Conclusion}

This study was conducted to investigate how the values of universities regarding core competencies are perceived at the workplace and specifically identify the nature of those discrepancies if any. In order to accomplish this, first, seven core competencies were identified through literature reviews and focus group interviews with professors. Surveys mainly asked the professors to select and rank, among the 7 competencies, the three most important competencies for college students. Employees were also asked to select and rank the three most important competencies required to successfully perform tasks in the workplace. Results demonstrate that university professors valued professional knowledge and creativity, while the business sector valued social skills, and values and attitude. Chi-square analysis demonstrated significant differences for the first and second rated competency between the two groups.

Results of this study indicate that higher education institutions and businesses share little when it comes to views on core competencies. Competencies emphasized in one group are also not valued by the other group. It is possible that this disagreement is due to the different roles and expectations imposed on university professors and corporate workers. Nonetheless, this disagreement suggests that what is being taught at universities may not be what is most needed at the workplace.

Does this discrepancy mean that the purpose of university education and business needs may not meet but in fact run in parallel lines? In order to answer this question, it is necessary to examine other factors besides organizational differences that influence perceptions on core competencies. One of these factors is the conventional perception on personality development. The widespread notion that there is a critical period in human development, mostly in the 
earlier years of life (Bailey, 2002), may have influenced university professors' opinions about the necessity for social skills development of college students. The fact that university professors expressed their concerns about the lack of social skills of college students during focus group interviews for eliciting the 7 core competencies used in this study, imply that professors may have recognized social skills as skills which should have been developed prior to entering college ("Students cannot deliver their thoughts in a logical manner.'. the environment they grew up have made them incompetent when it comes to interpersonal skills...", "I think students have become more and more inconsiderate of others due to small family size...").

However, in contrast to the general notion that human development is mainly accomplished during a certain window of opportunity, research in developmental psychology suggests otherwise. According to Gopnik, Meltzoff, and Kuhl (2000), even though the foundation of development is established during adolescence, once the foundation is formed, learning can occur as a lifelong process. Studies on development focused on ages 18-25 (Arnett, 2000; Cohen, Kasen, Chen, Hartmark \& Gordon, 2003) define this stage as "emerging adulthood" (Arnett), a distinct and volatile developmental stage characterized by exploration of many possibilities in life. Typically this stage refers to people around 18-25 years old, those who consider themselves neither adolescents nor adults capable of change and growth in character, independence and perspective. The possibility of change in character and views on work, love, and life at this stage suggests higher education institutions may have to play a more active role in building social skills as well as cognitive skills.

The role higher education institutions might play in developing social skills is supported not only by psychological theories on emerging adulthood, but also by the importance of collective knowledge building practice ubiquitous in any profession in a knowledge based economy. People accumulate professional knowledge through social relationships where interpersonal interactions and human networking actively occur. Professional knowledge and social skills are closely linked together (Eraut, 1994; Tynjälä, Slotte, Nieminen, Lnka \& Olkinuora, 2006). It is possible that professors already recognize the importance of social skills for building professional knowledge, but are not prepared or willing to incorporate social skill building in their teaching practices.

Other findings of this study include the disregard of creativity by employees, although creativity was considered important by university professors. What is more interesting is that this result is contradictory in that participants are employees in the service or design 
department of businesses where creative ideas should be valued, and that creative talent is considered highly critical for success in today's business world. Then, why is creativity not valued at the workplace? In times of rapid change and endless competition, current business environments demand people to be creative and produce innovative ideas. However, one cannot ignore the possibility that certain factors such as work environment, culture, or the practical process for executing tasks at work may not advocate creativity. Individual creativity is promoted by work environments supportive of creativity (Amabile, 1996). However, the culture of the workplace, top-down management styles or hierarchical systems may not foster creative work. For instance, inept rewards for creativity, work overload, lack of learning opportunities, and autocratic leadership may contribute to difficulties for manifesting creativity at the workplace (Amabile). It would be difficult to be productive in a system where creative individuals are not encouraged to be so. Research on transition of corporate training (Baldwin \& Ford, 1998; Brinkerhoff, 2006; Brinkerhoff \& Montesino, 1995) suggest that work environments can limit the outcomes of training. Specifically, success of training programs depends not only on the qualities of the programs, but also on the support and interest shown by superiors and colleagues. These studies indicate that even if universities educate students to be creative, if the work environment and culture is not mature enough to allow people to display their creativity, then the mismatch between the two sectors will always exist. The type of workers demanded by businesses, and the type of workers actually produced by higher education will be different.

One other important finding is that university professors consider professional knowledge as the most important competency, while the business sector does not value that competency as much as university professors do. Although it is natural for university professors to stress professional knowledge, the problem is that professional knowledge taught at universities may have little relevancy to real tasks at the workplace, thus making businesses invest a lot of resources into training entry level workers or retraining existing workers. In this time of rapid change in society, businesses acknowledge that higher education cannot teach knowledge and skills readily available for the workplace (Yang et al., 2006). Despite the situation, the need for workers equipped with professional knowledge useful for the workplace still continues to exist.

Limitations of this study are, first, the perceptions of CEOs were not collected as the aim of this research was to identify perceptions of the workers actually executing tasks at the 
workplace. Future research should include perceptions of people from various positions, as perceptions of CEOs might differ from those of workers at the lower levels. Secondly, the distribution of age of the two participant groups may have influenced the data. A majority of the professors $(92.5 \%)$ were 40 or over, compared to $65 \%$ of the participants in their 30 's for the other group. Although differences are inevitable due to the nature of the occupations of the two groups, it is recommended that future studies should include a wide distribution of all age levels. Third, higher educational institutions may not be effective at developing creativity. The importance that professors put on creativity does not necessarily imply that universities are producing highly creative workers. Perceptions of the importance of the competencies were identified to compare what differences exist in the competencies required to conduct work successfully in the workplace. 
References

Amabile, T. M. (1996). Creativity in context. Boulder, CO: Westview Press.

Arnett, J. J. (2000). Emerging Adulthood: A theory of development from the late teens through the twenties. American Psychologist, 55, 469-480.

Astin, A. (2001). What matters in college: Four critical years revisited. San Francisco: Jossey-Bass.

Baek, S. J., Kim, S. B., \& Chun, J. S. (2006). Policy measures for higher education development from the human resources development perspective. Korea Research Institute for Vocational Education \& Training.

Bailey, Jr., D. B. (2002). Are critical periods critical for early childhood education? The role of timing in early childhood pedagogy. Early Childhood Research Quarterly, 17, 281-294.

Baldwin, T. T., \& Ford, J. K. (1998). Transfer of training: A review and directions for future research. Personnel Psychology, 41, 63-105.

Barnett, R. (2009). Knowing and becoming in the higher education curriculum. Studies in Higher Education, 34, 429-440.

Beechler, S, \& Woodward, I. C. (2009). The global "war for talent". Journal of International Management, 15, 273-285.

Bertsch, T. (2000). Planning for results-oriented higher education in the 21st century. Advances in Competitiveness Research. Retrieved October 12, 2009, from

http:/ / www.allbusiness.com/human-resources/careers-job-training/718442-1.html.

Blumenstyk, G. (2001). Knowledge is a form of venture capital for a top Columbia administrator. Chronicle of Higher Education, 47, A29-A31.

Brinkerhoff, R. O. (2006). Getting real about evaluation. Training + Development, May, 24-25.

Brinkerhoff, R. O., \& Montesino, M. U. (1995). Partnerships for training transfer: Lessons from a corporate study. Human Resource Development Quarterly, 6, 263-274.

Chew, E. B., \& McInnis-Bowers, C. (2004). Blending liberal art and business education. Liberal Education, 90 (1), 56-63.

Cohen, P., Kasen, S., Chen, H., Hartmark, C., \& Gordon, K. (2003). Variations in patterns of developmental transitions in the emerging adulthood period. Developmental Psychology, 39, 657-69. 
Craft, A. (2006). Creativity in schools' education. In J. Norman, M. Oliver, M. Shay, and J. Wisdom (eds.), Developing creativity in higher education: An imaginative curriculum (19-28). London: Routlege Falmer.

Eraut, M. (1994). Developing professional knowledge and competence. Bristol, PA: Taylor \& Francis.

European Commission. 2009. A new partnership for the modernisation of universities: The EU Forum for University Business Dialogue. European Communities.

Giroux, H. A. (2003). Selling out higher education. Policy Futures in Education, 1 (1), 179-200. Gopnik, A., Meltzoff, A. N., \& Kuhl, P. K. (2000). The scientist in the crib: What early learning tells us about the mind. New York: HarperCollins.

Grubb, W. N., \& Lazerson, M. (2005). Vocationalism in higher education: The triumph of the education gospel. Journal of Higher Education, 76 (1), 1-25.

Hodeges, D \& Burchell, N. (2003). Business graduate competencies: Employers' views on importance and performance. Asia-Pacific Journal of Cooperative Education, 4 (2), 16-22. Humphreys, D. (2006). Making the case for liberal education: Responding to challenges. Washington, DC: Association of American Colleges and Universities.

Hutchins, R. M. (1968). The Learning Society. New York: Praeger.

Jin, M., Lee, S., \& Song, C. (2007). Identification of college students' core competencies and survey development. Korean Ministry of Education.

Jones, R. T. (2005). Liberal education for the business expectations. Liberal Education, 91 (2), 32-37.

Jung, C. (1998). Linking core competencies and national curriculum. Monthly Education, July (199).

Kim, A. N., Kim, N. H., Kim, T. J., Lee, S. J., \& Jung, H. O. (2003). The research on the national standards of life skill and quality management for learning system $\Pi$. Korean Educational Development Institute.

Le Deist, F., \& Winterton, J. (2005). What is competence? Human Resource Development International 8 (1), 27-46.

Lim, U., Choi, D., \& Park. M. (2008). Core competencies for future jobs. Korea Research Institute for Vocational Education \& Training.

Lustig, J. (2005). The university revisioned: An alternative to corporate mis-education. The Review of Education, Pedagogy, and Cultural Studies, 27, 17-52. 
McClelland, D. C. (1973). Testing for competence rather than for intelligence. American Psychologist, 28 (1), 1-14.

McLagan, P. (1989) Models for HRD practice: The Models. Washington D.C: American Society for Training and Development.

Na, S., Jang, S., Seo, W., Kim, J., Lee, S., Kim, K., \& Jung, S. (2003). Key competencies required for the Korean workforce. The Journal of Agricultural Education and Human Resource Development, 36 (4), 139-158.

Navarro, P. (2008). Business schools: A study in failure. Business Week Online. Retrieved July 20, 2009 from, http://www.businessweek.com.

Norton, R. E. (1997). DACUM Handbook. Columbus, Ohio: Center on Education and Training for Employment College of Education, The Ohio State University.

OECD (2005). The definition and selection of key competencies: Executive summary. Retrieved March 3, 2009, from http://www.oecd.org.

Oh, E. J. (2002). Strategies for transitions from college to the enterprise. The Journal of Vocational Education Research, 21, 441-458.

Park, S., \& Song, Y. (2008). Different perceptions on college-graduated employee's competency: HRD practitioners vs. college students. Journal of Corporate Education, 10 (1), 27-45.

Raybould, J., \& Sheedy, V. (2005). Are graduates equipped with the right skills in the employability stakes? Industrial and Commercial Training, 37 (5), 259-263.

Rychen. D. S., \& Salganik, L. H. (2003). A holistic model of competence. In D.S. Rychen and L. H. Salganik (eds.), Defining and selecting key competencies (41-62). Seattle: Hogrefe \& Huber.

Smith, R. B. (1987). The liberal arts and the art of management In Educating managers: Executive effectiveness through liberal learning, ed. Johnston et al., 21-33. San Francisco: Jossey-Bass.

So, K. H. (2006). 'Competency' in the context of schooling: It's meaning and curricular implications. The Journal of Curriculum Studies, 24 (3), 39-59.

Spencer, L., \& Spencer, S. (1993). Competency at work: Models for superior performance. New York: Wiley.

Tynjälä, P., Slotte, V., Nieminen, J., Lnka, K., \& Olkinuora, E. (2006). From university to working life: Graduates' workplace skills in practice. From Higher Education and 
Working Life: Collaborations, confrontations and challenges by P. Tynjala, J. Valima, \& G. Boulton-Lewis (Eds.) Oxford, UK: Elsevier.

Wheelahan, L. (2007). How competency-based training locks the working class out of powerful knowledge: A modified Bernsteinian analysis. British Journal of Sociology of Education, 28, 637-651.

Yang, S., Kim, H., \& Joo, K. (2006). A study of companies' perception on university education and their needs. Journal of Vocational Education and Training, 9, 145-170.

Yoo, T., Kim, Y., Park, H., Shim, Y., Kim, J., Kim, S., Kim, S., \& Ahn, Y. (2008). The content analysis of desirable talent in Korean companies. Paper presented at the annual conference of the Korean Psychological Association, 264-65.

* 논문접수 2010년 9월 16일 / 1차 심사 2010년 11월 11일 / 2차 심사 2010년 12월 11일/ 게재승인 12월 17일

* 오헌석(吳憲錫, Hunseok Oh): 서울대학교 국민윤리교육과를 졸업하고 교육행정사무관으로 공직에 몸담고 있다가 미국 미네소타대학에서 '인적자원개발 박사학위를 취득했다. 현재는 서울대학교 교육학과 교수로 재직 중이며, 인적 자원 개발 전략 및 전문성에 관한 연구를 주요 분야로 하고 있다. 2005년부터 한국 능률협회 ASTD 코디네이터 교수로 참여하였고, 한국인력개발학회 인력개발연구 편집위원장을 맡고 있다. 저서로는 『세계를 이끄는 한국의 창조적 공학자들』, 『세계를 이끄는 한국의 최고 과학자들』, ${ }^{『} \mathrm{ASTD}$ 인적자원개발 트렌드』등이 있다.

*E-mail : ohhs@snu.ac.kr

* 이예경(李澧增, Yekyung Lee): 서울대학교 교육학과를 졸업하고 미국 Purdue University에서 교육공학으로 박사학위를 취득하였다. 서울대학교 한국인적자원연구센터 박사후 연구원을 역임하였으며, 현재 서강대학교 교육대학원 교수로 재직 중이다. 관심연구 분야는 디지털 교과서 개발, 자기주도성 학습, 이러닝 개발, 비판적 사고력 향상 등이다.

*E-mail : ylee5@sogang.ac.kr 


\section{논문 요약}

\section{핵심역량에 대한 대학과 기업 간의 인식 차이에 관한 연구*}

오헌석**

이예경***

핵심역량에 대한 대학교와 기업 간 존재하는 인식차이를 탐색하기 위하여 본 연구는 대학 교수들을 대상으로 실시된 집단 인터뷰와 문헌연구를 통하여 7 가지 핵심역량을 도출해 낸 후, 대학교수와 기업 종사자 집단을 대상으로 7 가지 핵심역량에 대한 우선순위를 분석하였다. 총 158 명의 대학교수와 242 명의 기업 종사자들이 설문에 답하였다. 설문 결과, 대학교수 집단 이 전문적 지식과 창의성을 중시하고 있는 반면, 기업 종사자 집단은 사회적 기술과 가치·태도 를 가장 중요한 핵심역량으로 인식하고 있는 것으로 드러났다. 즉, 대학교수들이 중시하는 핵심역량이 기업 종사자들에게는 중요한 직업능력으로 인식되고 있지 않았다. 또한, 기업에서 창의성을 중시한다는 세간의 인식과는 반대로 기업종사자들은 창의성을 중요한 직업능력으 로 간주하고 있지 않았다. 본 연구의 시사점으로는 최근의 발달심리학적 이론에 근거하여 사회성과 가치 및 태도와 같은 인성적 측면의 변화가 대학생에게도 충분히 일어날 수 있다는 관점에서 대학에서도 사회성 등의 역량을 함양시킬 수 있다는 생각의 전환이 필요하며, 기업 에서는 창의성 발현을 가로막는 조직 분위기와 환경을 개선해 나갈 필요가 있다는 것이다.

주요어: 역량, 창의성, 사회성, 대학 교육, 직업 능력

* 이 연구는 교육과학기술부의 지원을 받아 한국인적자원연구센터에 의해 수행되었음.

** 서울대학교 사범대학 교육학과 교수, 한국인적자원연구센터 소장

*** 교신저자, 서강대학교 조교수 